\title{
Decoupling processes and scales of shoreline morphodynamics
}

Hapke, Cheryl J. ${ }^{* a}$, Plant, Nathaniel G. ${ }^{\text {a, }}$ Henderson, Rachel. E. ${ }^{\text {a }, ~ S c h w a b, ~ W i l l i a m ~ C . ~}{ }^{\text {, }}$, Nelson, Timothy R. ${ }^{\mathrm{a}}$

* corresponding author (chapke@usgs.gov)

${ }^{a} U . S$. Geological Survey

St. Petersburg Coastal and Marine Science Center $6004^{\text {th }}$ St South

St Petersburg, FL 33701

${ }^{\mathrm{b}}$ U.S. Geological Survey

Woods Hole Coastal and Marine Science Center

384 Woods Hole Rd

Woods Hole, MA 02543 


\title{
Decoupling processes and scales of shoreline morphodynamics
}

\author{
Hapke, Cheryl J., Plant, Nathaniel G., Henderson, Rachel. E., Schwab, William C., Nelson,
}

\section{Timothy R.}

1. Abstract

Behavior of coastal systems on time scales ranging from single storm events to years and decades is controlled by both small-scale sediment transport processes and large-scale geologic, oceanographic, and morphologic processes. Improved understanding of coastal behavior at multiple time scales is required for refining models that predict potential erosion hazards and for coastal management planning and decision-making. Here we investigate the primary controls on shoreline response along a geologically-variable barrier island on time scales resolving extreme storms and decadal variations over a period of nearly one century. An empirical orthogonal function analysis is applied to a time series of shoreline positions at Fire Island, NY to identify patterns of shoreline variance along the length of the island. We establish that there are separable patterns of shoreline behavior that represent response to oceanographic forcing as well as patterns that are not explained by this forcing. The dominant shoreline behavior occurs over large length scales in the form of alternating episodes of shoreline retreat and advance, presumably in response to storms cycles. Two secondary responses include long-term response that is correlated to known geologic variations of the island and the other reflects geomorphic patterns with medium length scale. Our study also includes the response to Hurricane Sandy and a period of post-storm recovery. It was expected that the impacts from Hurricane Sandy would disrupt long-term trends and spatial patterns. We found that the response to Sandy at Fire Island is not notable or distinguishable from several other large storms of the prior decade.

Keywords: Shoreline change, coastal evolution, storm response, empirical orthogonal function,

Fire Island

\section{Introduction}

In the aftermath of extreme storm events there tends to be an increased societal focus on understanding the processes that control variations in coastal response, such as shoreline erosion and recovery. Such knowledge can be used for the development and refinement of models that predict future coastal behavior, and provides fundamental information needed to understand coastal vulnerability and resiliency. It is important to consider the relative roles of the various drivers of coastal change and the time scales of their influence when developing predictive 
models of coastal evolution in geologically and oceanographically complex coastal systems such 34 as barrier islands.

Hydrodynamics are a primary driver of coastal change. Water levels and currents

36 associated with waves, surge and tides interact with beach and bar morphology and associated

37 sedimentary deposits to drive beach and shoreline response during single storm events and

38 stormy periods (Lippman and Holman, 1990; Plant et al., 1999; Sallenger, 2000; Stockdon et al., 2006; Wright and Short, 1984) and over longer timescales (e.g., Yates et al., 2009). The alongshore variability of wave energy reaching the coast can be influenced by the orientation of

41 the coast, the bathymetry of the adjacent inner shelf and shoreface, and the morphology of the

42 nearshore bar and surf zone. Morphodynamic response of a beach during storms is driven by

43 hydrodynamic processes, but other factors, such as alongshore variations in beach and shoreface

44 slope, island elevation, and sediment availability may also impact short-term beach response

45 (Tătui et al., 2014; Wright and Short, 1984).

Longer-term behavior (years to decades) of the shoreline is the result of hydrodynamic and

47 morphodynamic processes acting over multiple stormy and intervening calm periods during

48 which the advanced or retreated state of the shoreline may be increasingly influenced by

49 sediment supply and geology (Houser et al., 2008; Morton et al., 2007; Viles and Goudie, 2003;

50 Woodroffe, 2003). Determining the relationship between shoreline processes and the response of

51 the shoreline over a continuum of time scales requires data of sufficient temporal and spatial

52 resolution and extent to resolve these scales (Stive et al., 2002).

Shoreline data capable of resolving storm events, annual and multi-decadal response are

54 uncommon, and as a result few studies have examined shoreline behavior over a broad range of

55 time scales. And while oceanographic forcing parameters (e.g., offshore wave height and 
direction) can be evaluated over long time periods using data from wave buoys and tide gauges,

57 or from modeled hindcast results (U.S. Army Corps of Engineers Wave Information Studies, for example). However, hydrodynamic processes alone are not sufficient to explain all shoreline

59 variability over multiple time and space scales. Internal characteristics (e.g., framework geology and geomorphology) of barrier island systems exert control on both the long-term and/or short-

61 term responses to the hydrodynamics.

Studies abound in the literature that describe the importance of framework geology on barrier island coastal evolution and response. The foundational studies of Belknap and Kraft 64 (1985) and Riggs et al. (1995) related characteristics of the underlying stratigraphy of the inner continental shelf in North Carolina, including stratigraphic variations and sediment availability, to barrier island evolution over long temporal scales. Schwab et al. $(2000 ; 2013)$ extended the

67 North Carolina studies to examine the relationship between stratigraphic and lithologic variations 68 in the pre-Holocene and Holocene deposits of the inner continental shelf off Fire Island, New 69 York, and centennial scales of shoreline change. McNinch (2004), Miselis and McNinch (2006) and Schupp et al. (2006) built on the previous works but focused on smaller scales of framework

71 geology and shoreline change. The studies examined the occurrence of paleochannels and

72 deposits within the shoreface along a single barrier island and found a relationship between the 73 patterns of decadal shoreline change and variable sediment availability, with shoreline erosion in 74 areas dominated by paleochannels.

Hapke et al. (2010; 2011b) established the relationship between shoreline change on a 76 variety of time scales (decades to century) and the modern morphology and framework geology 77 of the inner shelf at Fire Island. Persistent shoreline undulations were shown to occur 78 coincidently with the section of the island where a shoreface-attached ridge system extends into 
79 the very nearshore ( 3-4 $\mathrm{m}$ water depth) and appears to influence hydrodynamic processes.

80 Further, Lentz et al (2013) spatially correlated decadal beach-dune morphology and response,

81 including zones of persistent overwash, to variations in storm wave water levels that are related

82 to bathymetric variations on the inner shelf. Thus, the framework geology, which controls the

83 bathymetric variability is shown to be linked to island response on storm to decadal scales.

84 The above introduction is by no means a complete overview of the research that has

85 established linkage between framework geology and coastal response. Such an effort is outside

86 the scope of this paper. However, the examples and references therein provide the foundational

87 knowledge that framework geology has an important and demonstrable influence on rates and

88 trends of shoreline change on a variety of time scales. A question that remains is what is the

89 relative importance of storm processes versus geological control on storm response and multi-

90 decadal evolution of barrier islands?

91 In this paper, we utilize a statistical approach to examine spatial and temporal variations in

92 the morphologic evolution and response of the shoreline at Fire Island, NY, and relate the

93 behaviors to the influences of geology and storm processes. In addition, we take advantage of an

94 enhanced temporal resolution of our shoreline data to capture the short-term response of a recent 95 extreme storm event.

96 We hypothesize that there are separable patterns in shoreline response that can be utilized

97 to examine the role of oceanographic forcing of storms of varying sizes versus geologic control.

98 There may be feedback between the different components that alter how the system responds if

99 there are large shifts in morphology or geology. For instance, large storms could change the

100 distribution of sediment supply and alter subsequent patterns of short-term and long-term

101 response. Hurricane Sandy (landfall on Oct. 29, 2012, near Atlantic City, NJ) is an event that we 
102 investigate to explore whether extreme storms alter the stability of the island, altering the 103 relationship between geology and long and short time-scale behavior.

Fire Island is an ideal locale for examining this relationship due to the complex, but well105 documented framework geology, distribution of sand deposits on the inner shelf, and variable 106 bathymetry and island topography (Hapke et al., 2011b; Leatherman, 1985; Lentz and Hapke, 107 2011; Lentz et al., 2013; Schwab et al., 2000; 2013; 2014). We utilize an extensive database of 108 shoreline positions that extends over a time period of 81 years to examine the morphodynamics 109 of the shoreline over multiple time scales and assess the dominant controls on the spatial 110 variations and temporal trends. The variance in the time series is analyzed using empirical 111 orthogonal functions (EOF) to statistically evaluate temporal trends and spatial patterns that 112 dominate the shoreline behavior. This approach allows us to decompose the complex time series 113 to isolate the relative importance of the factors controlling shoreline behavior and the scales over

114 which they have influence. We then describe the different modes, attribute them to 115 oceanographic, geologic, or feedback processes, and identify what processes control shoreline 116 variability at different spatial and temporal scales.

\section{Oceanographic and Geologic Setting}

119 Fire Island is part of the barrier island system that flanks the south shore of Long Island, 120 New York (Fig. 1). The island is oriented east-northeast and extends for 50-km from Fire Island

121 Inlet in the west to Moriches Inlet in the east. Both inlets are stabilized with jetties and 122 periodically dredged to maintain navigation channels. The Fire Island coastal system is wave123 dominated, microtidal, with a tidal range of $1.3 \mathrm{~m}$ (NOAA, 2014). Sediment transported along 124 the shore of Fire Island is primarily from east to west, driven by the predominant wave approach 
125 out of the southeast (Leatherman, 1985). The ocean coastline of Fire Island is modified by

126 storms and subsequent recovery. The most common severe storms are extratropical (nor'easter)

127 systems that occur seasonally, typically from November through April. Nor'easters tend to have

128 durations extending over multiple tidal cycles, generally 2-5 days. In contrast, hurricanes directly

129 impact Fire Island less frequently and in general are faster moving systems, with impacts

130 occurring over one or two tidal cycles, typically lasting less than 24 hours (Birchler et al., 2014).

131 Historic storms of note can be identified from reports of widespread erosion, overwash,

132 breaching, and infrastructure damage along this coastline. Examples of such storms include the

1331938 Hurricane, the 1962 Ash Wednesday storm, a series of powerful nor'easters in 1991, 1992

134 and 1993, and Hurricane Sandy in 2012. Significant wave heights during Hurricane Sandy

135 reached the highest levels on record, 9.6 m (from NDBC wave buoy \#44025) (Hapke et al., 136 2013).

137 Distinct variations in the morphology of the inner continental shelf and modern sediment 138 distribution patterns offshore of Fire Island (Schwab et al., 2013; 2014) allow the system to be 139 divided into three distinct geologic zones. Remnants of a Pleistocene glaciofluvial outwash lobe 140 define a submerged headland offshore of central Fire Island (Fig. 1). The zone is more gently 141 sloping than the adjacent areas and contains thicker deposits of sediments. To the east of the 142 submerged headland, relatively older Pleistocene outwash is exposed over much of the inner 143 continental shelf; little modern sediment exists in this zone (Schwab et al., 2000; 2013; 2014).

144 The morphology of the inner continental shelf offshore of western Fire Island is dominated by a 145 field of shoreface-attached sand ridges that migrate in a westerly direction (Duane et al., 1972;

146 Schwab et al., 2013; 2014). 
147 The morphologic behavior and storm response of the island is relatively well documented and

148 both shoreline and profile morphodynamics have been related to the regional variations in inner

149 shelf geology (Hapke et al., 2013; Leatherman, 1985; Lentz and Hapke, 2011; Lentz et al., 2013;

150 Schwab et al., 2013). The historical record of shoreline change along Fire Island can be

151 separated into three zones which correspond to the three geologic zones identified on the inner

152 continental shelf. Schwab et al. (2013) noted that the rates of change are highly variable along

153 the coast with erosion along the eastern segment of the island $(-0.72 \pm 0.18 \mathrm{~m} / \mathrm{yr})$, modest

154 shoreline accretion in the central segment of the island $(0.38 \pm 0.07 \mathrm{~m} / \mathrm{yr})$ and mixed erosion and

155 accretion along the western segment (-0.12 \pm 0.14$)$. In this paper we refer to the different zones as

156 the western, central and eastern geologic zones (WGZ, CGZ, and EGZ).

157

158 4. Methods

159 4.1 Shorelines and Time Series Analysis

160 Shorelines incorporated into this analysis are largely derived from previous data

161 compilations (Table 1) (Hapke, et al., 2011a; Himmelstoss et al., 2010; Lentz et al., 2013;

162 Schwab et al., 2013). For this study, the extensive historical shoreline database is supplemented

163 with new data collected immediately prior to and after Hurricane Sandy (October - November

164 2012) and over a period of fifteen months after Sandy to document recovery (Henderson et al.,

165 2015). The post-Sandy shorelines are derived from field data acquired using DGPS survey lines

166 collected on the beach face and extracting the MHW contour from an interpolation of the survey

167 data (Hapke et al., 2013). Older shorelines (pre-1997) are based on interpretations of high-water

168 lines (HWL) from historical maps and wet-dry lines (WDL) identified in aerial photographs.

169 More recent shorelines (1997 to 2014) are mean high water (MHW) contours derived from lidar 
170 elevation datasets or ground surveys. Estimates of shoreline positional uncertainty contained in

171 this database (Table 1) were derived using methods established by Himmelstoss et al. (2010) and

172 Hapke et al. (2011a) by assessing the errors associated with the data sources, collection,

173 extraction or digitization of the shorelines, and summing the error terms in quadrature. This

174 uncertainty ranges from 1-5 meters.

175 Shoreline change rates using twenty-three shorelines from previous analyses (Hapke et 176 al., 2010; Schwab et al., 2013) and five additional shorelines are used to extend the long-term

177 record and examine the impact and recovery from Hurricane Sandy (Table 1). The shoreline

178 database contains numerous historical shorelines for years in which storms occurred but none of

179 the data were collected specifically to resolve storm events and subsequent recovery. The

180 additional data from 2012 - 2014 allows for a more detailed examination of an extreme storm

181 event (Hurricane Sandy) at Fire Island.

182 A regular time-series array is developed from mean-removed shorelines and allows

183 visualization of persistent trends, temporal oscillations and spatial variations of the shoreline.

184 The temporal mean shoreline position is calculated using the time series of shorelines (1933-

185 2014). This value is then subtracted from each observed shoreline position such that positive

186 values in Figure 2 represent shorelines that are seaward of the mean and negative values are

187 landward of the mean. The array is created using a linear Delauney triangulation to interpolate

188 between individual dates and locations to create a Triangulated Irregular Network (TIN). Where

189 there are large temporal gaps in the sampling record (for example between 1940 and 1960 in

190 figure 2), the interpolated grid cell values have a higher degree of uncertainty due to aliasing.

191 However, persistent variations are still clearly resolved. For example, the zone of erosion in the

192 area 18-20 km alongshore (Fig. 2) is persistent over long periods of time (1933 to 1989) and the 
193 interpolated grid provides a visual representation of the spatial continuity of that behavior 194 through time.

195 Shoreline change rates are calculated at $50 \mathrm{~m}$ intervals using the Digital Shoreline 196 Analysis System (DSAS; Thieler et al., 2009) to generate linear regression rates and other 197 change statistics (Fig. 3). The analysis does not include the very eastern and western portions of 198 the island, two and four kilometers from the inlets, respectively, in order to exclude the large 199 signals of accretion associated with the construction of the inlet jetties and associated inlet 200 bypassing in the case of Moriches Inlet.

201

The uncertainties for the linear regression rates are calculated following the method 202 outlined in Hapke et al. (2011a) and Hapke et al. (2013). The approach uses a spatially-lagged 203 autocorrelation (Garrett and Toulany, 1981) to determine the number of independent transects in 204 the area along which rates are being averaged. A quadrature average of the $95 \%$ confidence 205 interval (Taylor, 1997) is then determined using a reduced number of independent transects. 206

\subsection{EOF (Empirical orthogonal function) Analysis}

We use empirical orthogonal function analysis (EOF) as a tool for identifying coherent

209 spatial and temporal variability. EOF has been used in a variety of applications in coastal

210 systems. Most have applied the technique to evaluate dominant modes of variability in the cross211 shore direction (Houser et al., 2008; Wijnberg and Terwindt, 1995; Winant, et al.,1975; Yates et 212 al., 2011) while some researchers have used EOF to assess trends and patterns in alongshore 213 variability in shoreline position (Dick and Dalyrample, 1984; Munoz-Perez, et al., 2001; Miller 214 and Dean, 2007). In this study, EOF analysis is used to separate the spatial and temporal patterns 
215 of the mean-removed shoreline position data. The EOF analysis solves for independent modes

216 that can be used to reconstruct the input data as

$$
\dot{X}(y, t) \sim \sum_{m=1}^{M} A_{m}(t) F_{m}(y)
$$

where $X$ indicates the mean-removed shoreline position data, and $y$ and $t$ indicate alongshore

221 position and time, $\mathrm{A}_{\mathrm{m}}$ are temporal modes, $\mathrm{F}_{\mathrm{m}}$ are spatial modes, and the summation is over all

222 possible modes, M, which equals the number of spatial locations included in the analysis

$223(\mathrm{M}=839)$. To compute the EOF modes, spatial and temporal data gaps were filled prior to EOF 224 analysis via interpolation that used a smoothing filter (Plant et al., 2002) with 250-m half-width

225 in the alongshore direction and 1-month half-width in time. The temporal smoothing removed

226 very rapid fluctuations in cases where there were frequent surveys that sampled individual storm

227 response and recovery. Spatial gaps wider than $250 \mathrm{~m}$ were treated as missing data following the

228 approach of Davis (1976), which finds weighted values for the EOF amplitudes $\left(\mathrm{A}_{\mathrm{m}}\right)$ when data

229 are missing, reducing sample bias at times when the data are not complete. We define the EOF

230 spatial modes $\left(F_{m}\right)$ such that they are normalized to have unit variance and the temporal modes

$231\left(\mathrm{~A}_{\mathrm{m}}\right)$ carry the actual variance explained by each mode. The modes are sorted such that those

232 with the most variance are presented first and, as we will show, the first few modes are the only

233 ones that contain relevant signals and the later modes are attributed to noise. Additionally,

234 because the modes are, by definition, independent of each other, we can interpret each one

235 individually and attempt to assign different physical process or geological significance to each

236 one, independent of the other modes. 


\subsection{Wave Record Analysis}

To examine whether temporal variations in the EOF modes can be related to hydrodynamic forcing as opposed to geologic processes, we analyzed available wave and water level records and compared them to the EOF. We used Wave Watch 3 (WW3) data from 1979 to 2015, which consist of reanalysis hindcast data between January 1979 and January 2005. Historical observed data were used between February 2005 and January 2015 (http://polar.ncep.noaa.gov/waves/).

The wave time series is taken from a WW3 grid point offshore of Central Fire Island $\left(40.6^{\circ} \mathrm{N}\right.$ and $72.93^{\circ} \mathrm{W}$ ). Hourly water level observations from 1933 to 2015 were also obtained from the NOAA tidal station 8531680 located at Sandy Hook, NJ. Table 2 shows the mean and standard deviation of the wave characteristics averaged over 5 year periods.

\section{Results}

\subsection{Shoreline Morphodynamics}

The regular time series array of mean-removed residual shoreline position is shown in Figure 2 and shows 81 years of shoreline response. The temporal pattern of change includes advanced (shoreline seaward of the mean) or retreated (shoreline landward of the mean) states that persists for a period of time and then the patterns reverse. For example, the shoreline is in an advanced state in the pre-1950 period (Fig. 2). From 1950 to 1970, the shoreline is in a dominantly retreated phase. Beginning about 1970, the phase shifts back to an advanced phase for approximately 10 years, and then retreats again beginning about 1980 . The system appears to fall out of this oscillatory phase behavior from the 1990s to 2005 . Shorter duration cycles of shoreline advance and retreat are better resolved in the shoreline record in the near-term (Table 1) when the data are sampled more frequently. Prior to the 1990s, the sample frequency of the 
261 data is not sufficient to resolve smaller scale variations that would have occurred on time scales

262 of years, for instance during stormy periods versus non-stormy periods.

In addition to oscillations of shoreline position through time, there are also alongshore

264 zones of retreat or advancement that are spatially persistent over long time periods (Fig. 3). The

265 results of the linear regression analysis, conducted on the 81-year shoreline position dataset (Fig.

266 3), expand on those presented by Schwab et al. (2013), with an along-island average of $-0.11 \pm$

$2670.11 \mathrm{~m} / \mathrm{yr}$, which is not significantly different from zero. The rates are highly variable

268 alongshore, but the long-term trends are distinct within the three geologic zones of Fire Island.

269 EGZ shows relatively high rates of erosion $(-0.67 \pm 0.21 \mathrm{~m} / \mathrm{yr})$. CGZ is characterized by an

270 accretional trend (0.38 0.06$)$, and rates of change in WGZ are highly variable along the coast

271 with an average of $-0.06 \pm 0.16 \mathrm{~m} / \mathrm{yr}$ (no significant change).

272

$273 \quad 5.2$ Empirical Orthogonal Function Analysis

274 In the EOF analysis for the full time series (1933-2014, Figure 4), 67\% of the alongshore

275 position variability is described by three EOF modes, herein referred to as EOF1, EOF2 and

276 EOF3, explaining 33\%, 19\%, and 15\% of the variance, respectively. EOF1 has the same sign

277 (negative) along the length of the island, and, thus, represents shoreline changes that are in phase

278 with each other over the entire coast (Fig. 4a). This in-phase behavior can represent shoreline

279 response typical of cross-shore seasonal and storm behavior wherein the entire shoreline

280 advances or retreats in response to alongshore uniform driving forces (Miller and Dean, 2007).

281 EOF1 contains both short-scale and larger-scale spatial variability indicating differences in the

282 amplitude of the responses. For instance, at the far western end of the island, the amplitude is

283 nearly zero indicating that this mode describes very little of the variance there. The amplitude 
284 increases within the rest of WGZ, is somewhat smaller in CGZ, and increases again in EGZ.

285 There are slight negative trends in the mode from the central area of the island towards either end 286 with the exception of the near-zero west end of the island next to Fire Island Inlet.

287 The temporal eigenfunction associated with EOF1 indicates that there are strong

288 oscillations, which are consistent with storm response and recovery as the shoreline moves

289 landward and seaward across the entire region (Fig. 4b). The sparse sampling prior to the 1980s

290 might suggest a trend between the $2^{\text {nd }}$ and $3^{\text {rd }}$ observations where the temporal function

291 experiences a large change (and change in sign). However, it is likely that there were many

292 oscillations in the temporal response that were not resolved. After the early 1990s, the improved

293 resolution of the data shows that the amplitude variations are very noisy and oscillate around

294 zero through the remainder of the time series.

295

The EOF2 mode accounts for $19 \%$ of the variance in the time series. Spatial variability

296 associated with this mode includes distinct differences in behavior of the island (Fig. 4c). In the

297 WGZ, there is alongshore variation with a characteristic length scale of approximately 6

298 kilometers. There is a strong trend from high to low variance between EGZ to CGZ with a phase

299 reversal in the transition area between the two zones. The temporal coefficient of EOF2 shows

300 that the distinct spatial variation of the long-term shoreline behavior between zones is dominant

301 early in the time series ( pre-1970), and vanishes around 2000, and has an opposite sign

302 thereafter (Fig. 4d). This behavior corresponds to a large-scale change in the shoreline angle as

303 the east end of the island retreats landward, the middle accretes, and the west is variable but

304 stable, as documented by the linear regression shoreline change patterns (Fig. 3).

EOF3 describes $15 \%$ of the variance in the shoreline record. Spatial patterns include large

306 amplitude oscillations on the western half of the island with wave lengths of 6-7 km (Fig. 4e). 
The length scale of the oscillations in EOF3 are similar to the oscillations present in EOF2, but

308 the location of the peaks of the oscillations are spatially shifted, a requirement since the different

309 modes are uncorrelated. The temporal coefficient shows little coherent change until the mid-

310 1990s (Fig. 4f) when there is a progressive change in amplitude (it becomes negative), after

311 which there is a reversal in the amplitude (trending towards positive) until stabilizing during the

312 more recent dates ( post-2002) with a slight positive value. On the western half of Fire Island,

313 this indicates a change in the phase of the rhythmic features such that the locations where the

314 shoreline had been in an advancing state have reversed to a retreating state. The same is true for

315 the eastern half of the island, although the oscillations do not exhibit a systematic length-scaling

316 as observed on the western half of the island. The time-scale of change is much longer than

317 individual storms (EOF 1) and is shorter than the long-term trend (EOF2).

\subsection{Wave Record Analysis}

320 The results of the historical wave analysis is provided in Table 2 and shown in Figure 5a-d, 321 along with the first 3 temporal EOF coefficients (Fig. 5e). From 1980 to 2015, the average wave 322 height was $1.08 \mathrm{~m}$ and the wave period was $7.06 \mathrm{~s}$. The time series shows no apparent long term 323 trend in significant wave height $\left(\mathrm{H}_{\mathrm{s}}\right)$ or mean wave period $\left(\mathrm{T}_{\mathrm{m}}\right)$. There is a significant trend in the 324 wave direction $\left(\alpha_{\mathrm{w}}\right)$ that indicates a slight ( 3 degrees) northward rotation after 1995 (Table 2).

\section{$326 \quad 5.4$ Storm response}

327 In order to examine shoreline response to known storm events in the more recent, densely

328 sampled time period, including the response and recovery to Hurricane Sandy in 2012, we isolate 329 the more recent portion of the long-term time series, 1980 - 2014, from the data used to produce 
330 figure 4 (Fig. 6). The spatial eigenfunctions in figures 4 and 6 are the same for reference.

331 Known, individual large storms of the 2004-2014 time period are identified in all three of the

332 EOF amplitude time series (figs. 6b, 6d and 6f). In all modes, large storms result in similar

333 magnitude increases in amplitude. This includes the response from Hurricane Sandy, which was

334 in comparison a far larger storm based on wave height and period than the other notable storms

335 of the 2004-2014 record. One exception to the consistent storm response characteristic is the

336 large negative excursion in the amplitude of EOF3 in the period from $1990-2004$.

\section{Discussion}

Long-term time series of shoreline change provide an ideal dataset to understand the 340 relative importance of coastal change drivers on barrier island evolution. Our analysis of the 341 long-term time series at Fire Island indicates that the behavior and evolution of the barrier island, 342 as represented by multi-temporal shoreline positions and long-term trend, is controlled by a 343 combination of resolvable external and internal factors. The external factors are hydrodynamic 344 processes associated with storms and the internal factors are linked to the geology of the coastal 345 system in the form of variations in alongshore sediment availability and morphology 346 (bathymetric variability and slope).

\subsection{Hydrodynamic Process and Response}

Our analysis indicates that shoreline variability that is coherent at the largest spatial scale 350 (EOF1) is the most-rapidly changing, with fluctuations that are not usually resolved by the

351 temporal sample rate. While the EOF approach does not inherently identify patterns of 352 variability that represent different physical processes, the spatial coherence of EOF1 remains 
353 high across the entire study domain (with the exception of the very western portion, which is 354 known to be a migrating spit). Therefore, the EOF 1 characteristics are interpreted to identify a 355 physical process (e.g., rapid, spatially coherent storm response and recovery), rather than simply 356 breaking down a noisy signal, for which EOF1 would be expected to explain the most variance 357 in the central portion of the spatial domain (Merrifield and Guza, 1990) and progressively less 358 variance towards the domain boundaries. There is also distinct variability that is manifested in shoreline orientation (EOF2) and is 360 a large spatial-scale phenomenon that changes over the longest times scales (century). This trend 361 could be driven oceanographically, e.g., as a response to the subtle trend in wave angle, or it 362 could be a differential response controlled by the different geologic constraints present along the 363 island. Finally, shorter-length scale rhythmic features (EOF3) respond on intermediate 364 timescales (decades). We note that EOF analysis effectively separates the long-term and short365 term signals (e.g., EOF 1 and 2) from a data set with variable sampling in time. EOF analysis is 366 particularly appropriate for this irregularly sampled dataset, as it finds spatial patterns that 367 represent shoreline variability over the entire sample period and spatial extent. Alternatively, 368 focusing the analysis on only the more recent, more frequently sampled period leads to mixing of 369 the long-term and short-term signals and results in poor separation of trends. To test this, we 370 repeated the analysis on the period 1980 to present and found two dominant modes: the first was 371 essentially the same as our original EOF1 with a slight trend added to it and the second was 372 similar to EOF3. We also performed a complex EOF analysis (e.g., Merrifield and Guza, 1990) 373 which identified a dominant mode with nearly constant spatial phase (no alongshore 374 propagation), and rapid variation in temporal phase (a standing wave consistent with shoreline 375 erosion and deposition at short time scales). 
While EOF1 is coherent across the much of the analysis domain, there are short-scale

377 variations in its spatial pattern. The roll-off from a spatial autocorrelation of the amplitudes of

378 the spatial eigenfunctions indicates that the shorter features have length scales less than about 1

$379 \mathrm{~km}$. These are superimposed on the large-scale structure (Fig. 4a), which is visually apparent in

380 the time series array (Fig. 2). The oscillatory pattern of high variability with spatially alternating

381 retreat and advancement is indicative of storm-related response and recovery of the beach,

382 similar to reversing hotspots observed by List et al. (2006) and modeled by Valvo et al. (2006).

383 In this response mode, storm waves reorganize sediment along the beach face resulting in

384 distinct $\sim 1 \mathrm{~km}$ cells where the shoreline either retreats or progrades. Lower energy waves

385 gradually straighten the shoreline, thus reversing the storm shoreline configuration (Fig. 7a).

386 Although our data are not able to resolve on the intra-seasonal scales that were resolved by List

387 et al. (2006), our data do show patterns of persistence and reversal over longer time periods of

388 years to decades (Fig. 2). One explanation for the oscillatory pattern in the shoreline record is

389 that variations in temporal sediment flux that produce longshore sand waves result in gradual

390 shoreline advancement followed by retreat as packages of sand propagate alongshore (Hicks and

391 Inman, 1987; Stive et al., 1990; Stive et al., 2002). However, there is little evidence of

392 alongshore propagation of pulses of sediment at Fire Island (Fig. 2), in agreement with our

393 CEOF analysis and findings by Gravens (1999), with the exception of the time period from

394 approximately 1994 to 2002. The oscillations also appear abrupt (sub-year) based on the more

395 recent time period (Figs. $4 \mathrm{~b}$ and $6 \mathrm{~b}$ ), rather than a pattern of gradual (multi-year) retreat and

396 advancement, as is described for propagating sand waves. Temporary reversals in the sign of the

397 oscillations (retreated hotspots becoming advanced hotspots) are associated with major storm

398 events, for example Nor'Ida in 2009, Hurricane Irene in 2011, and Hurricane Sandy 2012 (Fig. 
6b). A return to a pre-storm state is indicative of recovery processes by which waves move

400

401

402

403

404

405

406

407

408

409

410

411

412

413

414

415

416

417

418

419

420

421

sediment landward in the surfzone as wave energy returns to non-storm conditions. The geomorphic manifestation of this process is that the shoreline becomes more variable for a period (sub-year) following storm events as sand is mobilized and deposited, reorganizing to return to a pre-storm state.

The short spatial scale $(<1 \mathrm{~km})$ storm-related oscillations superimposed on the alongshore-uniform structure of EOF1 is well correlated to the spatial variability of the longterm linear regression (correlation coefficient is 0.75 ), indicating that there is coupling between the long-term shoreline trends (which we interpret to be controlled by the framework geology) and the short-term variations associated with storms.

The data analyzed in this study includes shorelines before and after Hurricane Sandy, allowing for investigation of how extreme storms resolve in the long-term record as well as compare to severe, but lesser storm events. Hurricane Sandy was a significant event at Fire Island in terms of overwash, island breaching and dune elevation changes (e.g. Hapke et al., 2013). However, our analysis indicates that the shoreline response from Sandy was not unique in magnitude or character than other recent large storms such as Nor'Ida (2009) and Hurricane Irene (2011). Each of these storms, as well as moderately large nor'easters in 2005 and 2007, caused rapid phase shifts that were short-lived (years) (Figs. 6b, d, and f). The short duration of the impact and the lack of temporal trend in EOF1 and 3, suggests that, in the short term, the island is maintaining a relatively stable configuration. The beginning of a marked, long duration (15 year) negative excursion of the temporal amplitude in EOF3 coincides with major nor'easters of the early 1990s that severely impacted Fire Island. A similar response might be expected from a storm with the magnitude of Hurricane Sandy given the large amount of cross-shore transport 
422 that occurred during the storm, but there is no evidence for this in the shoreline variance. It 423 appears that the frequency and duration of the early 1990s storms altered the state of the 424 preferred shoreline configuration (Figs. 2 and 6c), possibly due to lack of sufficient recovery

425 time between major events. However, the winter following Sandy had a series of large nor'easter 426 events - seven storms with offshore significant wave heights of greater than four meters (Hapke 427 et al, 2013). The lack of anomalous signal in shoreline variance from Hurricane Sandy (as 428 compared to the 1990s nor'easters) is likely due to the substantial amount of sediment that was 429 mobilized during the storm. Although there was significant transport of material to the interior 430 and back-bay portions of the island (Hapke et al., 2013), large volumes were transported from 431 the beach and dunes to upper shoreface and were available for the short-term recovery of the 432 shoreline (Nelson and Hapke, 2015). The results suggest that extreme nor'easter storms or a 433 period of large storms in succession have the potential to disrupt long-term trends more 434 significantly and for longer time periods than isolated tropical storms at Fire Island (Figs. 2 and $4356 c)$

The lack of a temporal trend in the amplitude of EOF1, especially in the more recent

437 period from 1980 to 2014 (Figs. 4d and 6d), suggests that impacts of sea-level rise, effects of 438 island reorientation, and nourishment activities have not yet influenced the magnitude of storm 439 impacts at Fire Island. This supports other findings in our analysis that the Fire Island barrier 440 system is relatively resilient.

$442 \quad 6.2$ Geologic Processes and Evolution EOF2 has a distinct along-island spatial variability that consists of changes of sign in the 444 different island regions (WGZ, CGZ, EGZ) as well as short-scale spatial variability that is 
445 broadly distributed over length scales shorter than $5 \mathrm{~km}$. Alongshore variability in the long-term

446 shoreline change has been related to the geology in the form variations in slope of the beach

447 system (Lentz et al., 2013) and alongshore sediment availability and bathymetric features on the

448 inner continental shelf (Hapke et al., 2010; Schwab et al., 2000; 2013). These physical variations

449 have been established as representing framework geology variations and as thus defined can

450 influence the processes that shape the barrier island. The spatial pattern of EOF2 is strongly

451 correlated to the long-term linear regression of shoreline change (correlation coefficient is 0.92),

452 as expected since the temporal response of this mode is dominated by a long-term trend (Fig.

$4534 \mathrm{~d})$. We contend that the strong correlation between EOF2 and the long-term shoreline change

454 pattern statistically demonstrates the influence of geologic processes, or processes influenced by

455 framework geology, on barrier island evolution because the EOF analysis not only produces the

456 same patterns but shows that they are spatially coherent over very long length scales. Similar to

457 findings of Lazarus and Murray (2011) along the Outer Banks of North Carolina, when the

458 smaller length-scale, rapidly changing shoreline patterns are removed (EOF1), the patterns of

459 geologically-influenced long-term change are exposed. The long-term shoreline change rates

460 (Figs. 3 and 7b) provide evidence that the geomorphic expression of the island results from

461 persistent landward movement of the EGZ, seaward movement of the CGZ, and landward-

462 seaward oscillation in the WGZ.

463 Wave fields can be modified by variable shelf morphology (O’Reilly and Guza, 1993),

464 such as the paleo-outwash deposit in the CGZ or the sand ridge field in the CGZ and WGZ at

465 Fire Island, resulting in wave refraction that alters the hydrodynamics closer to the shoreline.

466 Additionally, ridge fields have been found to dissipate wave energy associated with storms along

467 the Dutch coast (van de Meene et al., 1996). Similar deposits exist adjacent to barrier islands 
468 along the U.S. eastern seaboard (Duane et al., 1972; McBride and Moslow, 1991; Schwab et al., 469 2000) and elsewhere, and the effects of these and similar features on barrier island evolution are 470 observed not only at Fire Island, but as demonstrated by Houser at al. $(2008 ; 2012)$ in the Gulf of 471 Mexico, and McNinch (2004) and Schupp et al. (2006) along the Outer Banks of North Carolina. 472 It is expected that the steeper and deeper morphology of the inner continental shelf off 473 the EGZ at Fire Island (Schwab et al., 2013) results in higher wave energy reaching this portion 474 of the coast (Davis, 1994) as compared to the CGZ and WGZ, increasing both cross-shore and 475 alongshore sediment fluxes. The steeper slope maintained by the beach system and higher cross476 shore sediment fluxes during storms (Lentz et al., 2013) is evidence of higher wave energy along

477 the EGZ. The steeper and deeper morphology in EGZ is a function of the variable framework 478 geology affecting evolutionary processes.

479 In addition, the volume of modern sand on the inner continental shelf along Fire Island, a 480 function of sediment thickness, is highly variable and the region offshore of the EGZ is largely 481 devoid of modern sediment (Fig. 1; Schwab et al., 2014). In contrast, the CGZ and WGZ have an 482 abundance of modern sediment. Schwab et al. (2014) provide evidence that the modern sediment 483 distribution extends into the lower shoreface. It is reasonable to assume that the relative 484 distribution of sand in the shoreface is a function of sand availability on the inner shelf and in 485 turn the distribution of sand in the littoral system a function of sand availability in the shoreface. 486 The volume and distribution of modern sand are thus a result of the framework geology. Material 487 transported inland as overwash and breaching during large storms is lost to the littoral system.

488 To maintain the shoreline position, sediment from the shoreface would be required to replenish 489 the lost littoral sediment, a process that is necessary to achieve the observed long-term 490 maintenance of the barrier island. 


\subsection{Additional Process Controls}

The final mode that we retain in the analysis, EOF3, consists of broad oscillations in the

494 WGZ and the western portion of the CGZ (length scale of $6.3 \mathrm{~km}$, based on spatial

495 autocorrelation) and describes high amplitude, large excursions along the length of Fire Island

496 (Fig. 4e). The spatial variations are only weakly correlated to the long-term linear regression

497 (correlation coefficient is 0.34 ), indicating that they are attributable to a process that differs from

498 the one driving long-term retreat and advancement of the shoreline identified in EOF2. The

499 largest wavelengths occur on the western half of the island and the retreat and advancement

500 excursions have a characteristic wave length that is similar in length-scale, but generally out of

501 phase, to the excursions in EOF2. The locations of focused shoreline retreat and advancement are

502 maintained over long periods of time with small amplitude increases that are storm-related (Figs.

5032 and 4f).

504 It is unclear what processes are creating and maintaining the large-scale oscillations, which

505 resembled a standing wave in both EOF2 and 3. Slight changes in the angle of wave approach

506 can alter the alongshore sediment flux and produce irregularities in the shoreline that could be

507 maintained if the wave direction persisted for some period of time (Ashton et al., 2001; Ashton

508 and Murray, 2006). Excursions in the shoreline maintained by a persistent wave approach may

509 become diffusive if the wave angle relative to the shoreline is reduced sufficiently. The wave

510 analysis (Table 2 and Figure 5) indicates that the wave angle relative to the shoreline at Fire

511 Island has slightly increased, which would increase the tendency for shoreline excursions. The

512 overall morphology of the island may not be persistently embayed because the processes creating

513 the oscillations in EOF2 and 3 are out of phase and may act together like a progressive wave that 
514 somewhat resembles alongshore propagating sand waves. The geomorphic expression of EOF3

515 is demonstrated in Figure 7c, which shows the decadal linear regression rates from 1988-1998, a

516 subset of our time series. The patterns of shoreline change during this period clearly show large

517 ( $\sim 6 \mathrm{~km}$ length scale) positive shoreline excursions indicating zones of progradation adjacent to

518 zones of retreat along the WGZ and the western portion of the CGZ, from $0-23 \mathrm{~km}$ alongshore.

519 The length scale decreases to the east and there is no evidence of a sustained length scale of the 520 retreat versus advanced cells.

521 The sign of the temporal coefficient of EOF3 remains the same over several decades (Fig.

$5224 \mathrm{f})$, leading to the persistence of the zones of advanced and retreated shorelines, with the

523 exception of a significant excursion that peaked in 1995. In the time period between 1990 and

524 1995, the zones reversed and their amplitudes increased rapidly. This major system

525 reconfiguration is associated with the series of severe nor'easter storms that occurred in rapid

526 succession in 1991, 1992, and 1993, and potentially forced an unstable state. Over a decadal time

527 period following the early 1990s nor'easters, the amplitudes steadily decreased and for the most

528 recent decade remain similar to pre-1990s magnitudes and sign (Fig. 6f). The eventual return to a

529 pre-1990s behavior (Figs. 2 and 6f) after the storms of the early 1990's supports that there is a

530 preferred configuration of the shoreline response, further demonstrating geological control and

531 overall island stability.

532

$533 \quad 6.4$ Management Implications

534 The separable and distinct behaviors which define shoreline morphodynamics and evolution

535 at Fire Island have significance for both coastal management and for the development and

536 refinement of predictive models. Management actions can benefit not only from the enhanced 
537 understanding of the along-island morphodynamics, but also through the recognition that specific

538 locations along the coast have a preferred response which may aid in decisions to manage

539 different sections of the island in different ways.

540

541 7. Conclusions

542 Our study of variance using empirical orthogonal function analysis of a long-term

543 shoreline database demonstrates that the primary controls on shoreline response along a

544 geologically-variable barrier island can be resolved on time scales ranging from storm events to

545 decadal variations over a period of nearly one century.

546 Short-term storm response and recovery dominates the shoreline behavior on the largest

547 spatial scales (along the entire barrier island). There is no conclusive indication of a trend

548 through time in the storm response mode of the shoreline implying that the Fire Island barrier

549 shoreline is stable over decade to century scales. In support of this conclusion is the shoreline

550 response to Hurricane Sandy in 2012, which was the largest storm on record for Fire Island but is

551 not differentiable from a number of severe but lesser storms of the previous decade.

552 The analysis of the long time series also provides a quantitative approach to support that

553 long-term shoreline evolution is controlled by the framework geology of the system represented

554 by known variations in inner shelf bathymetry, beach-shoreface morphology, and long-term rates

555 of shoreline change. The geologic processes that control long-term morphodynamics result in

556 the ends of the island responding in opposite phase to the central portion; this behavior is not

557 simply an artifact of the statistical methods approach since the long record of geomorphic change

558 of the barrier island also supports a geological control. The differential evolution of the barrier, 
therefore, is a function of the geological history of the region even prior to the formation of the

560 barrier itself.

An additional mode of variance in shoreline response reveals an intermediate-scale pattern that persists over both long and short-term time scales. Although speculative, we suggest that the pattern results from an unresolved combination of, or feedback between, storm processes and framework geology (bathymetric variability and sediment availability). The temporal record suggests there is a preferred configuration of shoreline response that can be periodically disrupted in association with major storms, but the deviations are not large and are short-lived (sub-year), supporting that the island is in a stable configuration. The exception to the stable configuration is the response associated with a period of frequent, severe nor'easters in the early 1990s; the recovery from this exceptionally stormy period took approximately a decade.

\section{Acknowledgements}

The data for this paper are available at the USGS National Assessment of Coastal Change Hazards Portal: http://marine.usgs.gov/coastalchangehazardsportal/ and from USGS Data Series 931 (http://pubs.usgs.gov/ds/0931/). Funding for this research was provided by the USGS Coastal and Marine Geology Program and the USGS Natural Resource Preservation Program. Owen Brenner provided field support and assisted with data acquisition and graphics. We would like to thank Jeff List and Jennifer Miselis (USGS) for fruitful discussions that enhanced the paper, Amy Farris (USGS) for assistance with code development and deriving shorelines. BJ Reynolds, Barry Irwin (USGS) and Jordan Rafael (NPS) provided valuable field assistance.

\section{References}

Ashton, A.D. and A.B. Murray, 2006. High-angle wave instability and emergent shoreline shapes: 1. Modeling of sand waves, flying spits, and capes. Journal of Geophysical Research 111, F04011, http://dx.doi.org/10.1029/2005JF000422.

Ashton, A.D, A.B. Murray and O. Arnoult, 2001. Formation of coastline features by largescale instabilities induced by high-angle waves, Nature 414, 296-300, http://dx.doi.org/10.1038/35104541. 
Belknap, D.F., and J.C. Kraft, 1985. Influence of antecedent geology on stratigraphic preservation potential and evolution of Delaware's barrier systems, Marine Geology 63, 235-262, http://dx.doi.org/10.1016/0025-3227(85)90085-4.

Birchler, J.J., P.S. Dalyander, H.F. Stockdon and K.S. Doran, 2015. National assessment of nor'easter-induced coastal erosion hazards-Mid- and northeast Atlantic coast: U.S. Geological Survey Open-File Report 2015-1154, http://dx.doi.org/10.3133/ofr20151154.

Davis, R. E., 1976. Predictability of sea surface temperature and sea level pressure anomalies over the North Pacific Ocean, Journal of Physical Oceanography 6, 249-266, http://dx.doi.org/10.1175/1520-0485(1976)006\%3C0249:POSSTA\%3E2.0.CO;2.

Davis, R.A., 1994. Barrier Island Systems - A Geologic Overview, in Davis, R.A. (Ed.), Geology of Holocene Barrier Islands, Springer-Verlag , pp. 1-48.

Dick, J.E., and R.A. Dalrymple, 1984. Coastal Changes at Bethany Beach, Delaware. Proceedings of the 19th International Conference on Coastal Engineering. ASCE Publishing, New York, NY, pp. 1650-1667.

Duane, D.B., M.E. Field, E.P. Meisburger, D.J.P. Swift, and S.J. Williams, 1972. Linear shoals on the Atlantic inner shelf, Florida to Long Island, in Shelf Sediment Transport, edited by D.J.P Swift, D.B. Duane, and O.H. Pilkey, pp. 447-449, Dowden, Hutchinson, and Ross.

Garrett, C.J.R., and B. Toulany, 1981. Variability of the flow through the Strait of Belle Isle, Journal of Marine Research 39, 163-189.

Gravens, M. B., 1999. Periodic Shoreline Morphology, Fire Island, New York, in Coastal Sediments, '99, edited by N. C. Kraus and W. G. McDougal, pp. 1613-1326, American Society of Civil Engineers, Reston, Va.

Hapke, C.J., E.E. Lentz, P.T. Gayes, C.A. McCoy, R.E. Hehre, W.C. Schwab, and S.J. Williams, S.J., 2010. A review of sediment budget imbalances along Fire Island, New York: can nearshore geologic framework and patterns of shoreline change explain the deficit? Journal of Coastal Research 26, 510-522, http://dx.doi.org/10.2112/08-1140.1.

Hapke, C.J., E.A. Himmelstoss, M. Kratzmann, J. List, and E.R. Thieler, 2011a. National Assessment of Shoreline Change: Historical Shoreline Change along the New England and Mid-Atlantic Coasts, U.S. Geological Survey Open-file Report 2010-1118, http://pubs.usgs.gov/of/2010/1118/.

Hapke, C.J., W.C. Schwab, P.T. Gayes, C. McCoy, R. Viso, E.E. Lentz, and J. List, 2011 b. Inner shelf morphologic controls on the morphodynamics of the beach and bar system, Fire Island, New York, in Coastal Sediments '11, edited by J.D. Rosati, P. Wang, T.M. Roberts, pp. 1034 - 1047, American Society of Civil Engineers, Reston, Va. 
Hapke, C.J., O. Brenner, R. Hehre, B.J. Reynolds, 2013. Coastal change from Hurricane Sandy and the 2012-13 winter storm season: Fire Island, New York, U.S. Geological Survey Open-File Report 2013-1231, http://pubs.usgs.gov/of/2013/1231/.

Henderson, R.H., C.J. Hapke, O.T. Brenner, and B.J. Reynolds, 2015. Hurricane Sandy beach response and recovery at Fire Island, New York: Shoreline and beach profile data, October 2012 to October 2014, U.S. Geological Survey Data Series 931, http://dx.doi.org/10.3133/ds931.

Hicks D.M. and D.L. Inman, 1987. Sand dispersion from an ephemeral delta on the Central California coast, Marine Geology 77, 305-318, http://dx.doi.org/10.1016/0025$\underline{3227(87) 90119-8 .}$.

Himmelstoss, E.A., M. Kratzmann, C. J. Hapke, E.R. Thieler, and J. List, 2010. The National Assessment of Shoreline Change: A GIS Compilation of Vector Shorelines and Associated Shoreline Change Data for the New England and Mid-Atlantic Coasts - U.S. Geological Survey Open-File Report 2010-1119, http://pubs.usgs.gov/of/2010/1119.

Houser, C., 2012. Feedback between ridge and swale bathymetry and barrier island storm response and transgression. Geomorphology 173, 1-16, http://dx.doi.org/10.1016/j.geomorph.2012.05.021.

Houser, C., C. Hapke, and S. Hamilton, 2008. Controls on coastal dune morphology, shoreline erosion, and barrier island response to extreme storms, Geomorphology 100, 223240, http://dx.doi.org/10.1016/j.geomorph.2007.12.007.

Lazarus, E. and A.B. Murray, 2011. An integrated hypothesis for regional patterns of shoreline change along the Northern North Carolina Outer Banks, USA, Marine Geology 281, 85-90, http://doi.org/10.1016/j.margeo.2011.02.002,

Leatherman, S.P., 1985. Geomorphic and stratigraphic analyses of Fire Island, New York, Marine Geology 63, 173-195, http://dx.doi.org/10.1016/0025-3227(85)90083-0.

Lentz, E.E., and C. Hapke, 2011. Geologic framework influences on the geomorphology of an anthropogenically modified barrier island: Assessment of dune/beach changes at Fire Island, New York, Geomorphology 126, 82-96, http://dx.doi.org/10.1016/j.geomorph.2010.10.032.

Lentz, E.E., C.J. Hapke, H.F. Stockdon, and R. E. Hehre, 2013. Improving understanding of near-term barrier island evolution through multi-decadal assessment of morphologic change, Marine Geology 337, 125-139, http://dx.doi.org/10.1016/j.margeo.2013.02.004.

Lippmann, T.C. and R.A. Holman, 1990. The spatial and temporal variability of sand bar morphology, Journal of Geophysical Research 95, C7, 11575- 11590, http://dx.doi.org/10.1029/JC095iC07p11575. 
List, J.H., A. Farris, and C. Sullivan, 2006. Reversing storm hotspots on sandy beaches: spatial and temporal characteristics, Marine Geology 226(3-4), 261-279, http://dx.doi.org/10.1016/j.margeo.2005.10.003.

McBride, R.A. and T.F. Moslow, 1991. Origin, evolution, and distribution of shoreface sand ridges, Atlantic inner shelf, U.S.A., Marine Geology 97, 57-85, doi:10.1016/0025-

3227(91)90019-Z.

McNinch, J.E., 2004. Geologic control in the nearshore: shore-oblique sandbars and shoreline erosional hotspots, Mid-Atlantic Bight, USA, Marine Geology 211, 121-141, http://dx.doi.org/10.1016/j.margeo.2004.07.006.

Merrifield, M. A. and R. T. Guza, 1990. Detecting propagating signals with complex empirical orthogonal functions: a cautionary note, Journal of Physical Oceanography 20, 1628-1633, http://dx.doi.org/10.1175/1520-0485(1990)020<1628:DPSWCE>2.0.CO;2.

Miller, J.K and R.G. Dean, 2007. Shoreline variability via empirical orthogonal function analysis: Part I temporal and spatial characteristics, Coastal Engineering 54, 111-113, http://dx.doi.org/10.1016/j.coastaleng.2006.08.013.

Miselis, J. L. and J. E. McNinch, 2006. Calculating shoreline erosion potential using nearshore stratigraphy and sediment volume: Outer Banks, North Carolina, Journal of Geophysical Research 111, F02019, http://dx.doi.org/10.1029/2005JF000389.

Morton, R.A., H.E. Clifton, N.A. Buster, R.L. Peterson, and G. Gelfenbaum, 2007. Forcing of large-scale cycles of coastal change at the entrance to Willapa Bay, Washington, Marine Geology 246, 24-41, http://dx.doi.org/10.1016/j.margeo.2007.07.008.

Munoz-Perez, J.J., R. Medina, and B. Tejedor, 2001. Evolution of longshore beach contour lines determined by the EOF method. Scientia Marina 65 (4), 393-402.

Nelson, T.R. and C.J. Hapke, 2015, Shoreface response and recovery to Hurricane Sandy: Fire Island, NY, in Coastal Sediments '15, edited by J.D. Rosati, P. Wang, G. Gelfenbaum, R. Guza, H. Hanson and P. Ruggiero, pp. 1034 - 1047, American Society of Civil Engineers, Reston, Va, doi:10.1142/9789814689977_0012.

NOAA, 2014. National Data Buoy Center, http://www.ndbc.noaa.gov/.

O'Reilly, W. C. and R.T.Guza, 1993.A comparison of two spectral wave models in the Southern California Bight. Coastal Engineering 19 (3), 263-282, http://dx.doi.org/10.1016/0378-3839(93)90032-4.

Plant, N. G., K. T. Holland, and J. A. Puleo, 2002. Analysis of the scale of errors in nearshore bathymetric data, Marine Geology 191, 71-86. doi:10.1016/S0025-3227(02)00497$\underline{8}$ 
Plant, N. G., R. A. Holman, M. H. Freilich, and W. A. Birkemeier (1999), A simple model for interannual sandbar behavior. Journal of Geophysical Research-Oceans 104(C7), 1575515776, doi:10.1029/1999JC900112.

Riggs, S.R., W.J. Cleary, and S.W. Snyder, 1995. Influence of Inherited Geologic

Framework on Barrier Shoreface Morphology and Dynamics, Marine Geology 126, 213-234, http://dx.doi.org/10.1016/0025-3227(95)00079-E.

Sallenger, A.H., 2000. Storm Impact Scale for Barrier Islands, Journal of Coastal Research 16, 890-895, http://coastal.er.usgs.gov/hurricanes/publications/jcr.html.

Schupp, C.A., J.E. McNinch, and J.H. List, 2006. Nearshore shore-oblique bars, gravel http://dx.doi.org/10.1016/j.margeo.2006.08.007.

Schwab, W.C., E.R. Thieler, J.R. Allen, D.S. Foster, B.A. Swift, and J.F. Denny, 2000. Influence of inner-continental shelf geologic framework on the evolution and behavior of the barrier-island system between Fire Island Inlet and Shinnecock Inlet, Long Island, New York, Journal of Coastal Research 16 (2). 408-422.

Schwab, W.C., W.E. Baldwin, C.J. Hapke, E.E. Lentz, P.T. Gayes, J.F. Denny, J.H. List, and J.C. Warner, 2013. Geologic evidence for onshore sediment transport from the inner-continental shelf: Fire Island, New York, Journal of Coastal Research 29 (3), 536-544, http://dx.doi.org/10.2112/JCOASTRES-D-12-00160.1.

Schwab, W.C., J.F. Denny, and W.E. Baldwin, 2014. Maps showing bathymetry and modern sediment thickness on the inner continental shelf offshore of Fire Island, New York. U.S. Geological Survey Open-File Report 2014-1203, http://dx.doi.org/10.3133/ofr20141203.

Stive, M.J.F., D.J.A. Roelvink, and H.J. de Vriend, 1990. Large-scale Coastal Evolution Concept, in $22^{\text {nd }}$ International Conference on Coastal Engineering, Delft, The Netherlands, 1962-1974.

Stive, M.J.F., S.G.J. Aaminkhof, L. Hamm, H. Hanson, M. Larson, K.M. Wijnberg, R.J. Nicholls, and M. Capobianco, 2002. Variability of shore and shoreline evolution, Coastal Engineering 47, 211-235, http://dx.doi.org/10.1016/S0378-3839(02)00126-6.

Stockdon, H.F., R.A. Holman, P.A. Howd, and A.H. Sallenger, 2006. Empirical parameterization of setup, swash, and runup, Coastal Engineering 53, 573-588, http://dx.doi.org/10.1016/j.coastaleng.2005.12.005.

Tătui, F., A. Vespremeanu-Stroe, and L. Preoteasa, 2014. Alongshore variations in beachdune system response to major storm events on the Danube Delta coast, Journal of Coastal Research, Special Issue No. 70, 693-699, www.jcronline.org/doi/pdf/10.2112/SI70-117.1. 
Taylor, J.R., 1997. An introduction to error analysis: The study of uncertainties in physical measurement, Sausalito, CA, University Science Books, pp. 327, http://dx.doi.org/10.1063/1.882103.

Thieler, E. R., Himmelstoss, E. A., Zichichi, J. L., \& Ergul, A., 2009. The Digital Shoreline Analysis System (DSAS) Version 4.0-An ArcGIS Extension for Calculating Shoreline Change, Geological Survey Open-File Report 2008-1278,

Valvo, L.M., A.B. Murray, and A. Ashton, 2006. How does underlying geology affect coastline change? An initial modeling investigation, Journal of Geophysical Research 111, F02025, http://dx.doi.org/ 10.1029/2005JF00340.

Van de Meene, J.W.H, J.R. Boersma, and J.H.J Terwindt, 1996. Sedimentary structures of combined flow deposits from the shoreface-connected ridges along the central Dutch coast, Marine Geology 131(3-4), 151-175, doi:10.1016/0025-3227(95)00074-7.

Viles, H.A., and A.S. Goudie, 2003. Interannual, decadal and multidecadal scale climatic variability and geomorphology, Earth Science Reviews 61, 105-131, http://dx.doi.org/10.1016/S0012-8252(02)00113-7.

Wijnberg, K.M. and J.H.J. Terwindt, 1995. Extracting decadal morphologic behavior from high resolution, long-term bathymetric surveys along the Holland coast using eigenfunction analysis, Marine Geology 126, 301-330, http://dx.doi.org/10.1016/0025-3227(95)00084-C.

Winant, C.D., D.L Inman, and C.E. Nordstrom, 1975. Description of seasonal beach changes using empirical eigenfunctions: Journal of Geophysical Research, 80(15), 1979-1986, http://dx.doi.org/10.1029/JC080i015p01979.

Woodroffe, C.D., 2003. Coasts: form, process and evolution, Cambridge, U.K., Cambridge University Press, pp 623.

Wright, L.D. and A.D. Short, 1984. Morphodynamic variability of surf zones and beaches: a synthesis, Marine Geology 56, 93-118, http://dx.doi.org/10.1016/0025-3227(84)90008-2.

Yates, M. L., R. T. Guza, and W. C. O'Reilly, 2009. Equilibrium shoreline response: Observations and modeling, Journal of Geophysical Research C: Oceans 114(9), doi:10.1029/2009JC005359

Yates, M.L., R.T. Guza, W.C. O’Reilly, J.E. Hansen, and P.L. Barnard, 2011. Equilibrium shoreline response of a high wave energy beach, Journal of Geophysical Research 116, 1-13, http://dx.doi.org/10.1029/2010JC006681. 
Table 1. Overview of shoreline data and uncertainty statistics

\begin{tabular}{|c|c|c|c|c|c|c|}
\hline Shoreline Dates & $\begin{array}{l}\text { Number of } \\
\text { Shorelines }\end{array}$ & $\begin{array}{l}\text { Uncertainty } \\
\text { (m) }\end{array}$ & $\begin{array}{c}\text { Shoreline } \\
\text { Proxy }\end{array}$ & $\begin{array}{l}\text { Shoreline } \\
\text { Originator }\end{array}$ & Data Source & $\begin{array}{l}\text { Data } \\
\text { Originator }\end{array}$ \\
\hline 7/01/1933, 7/01/1938* & 2 & 10.8 & HWL & USGS $^{1}$ & $\begin{array}{c}\text { T-Sheet, } \\
\text { Aerial } \\
\text { Photography }\end{array}$ & $\begin{array}{l}\text { NY Sea } \\
\text { Grant }\end{array}$ \\
\hline 7/01/1962, 7/01/1979* & 2 & 5.1 & $\begin{array}{c}\text { MHW, } \\
\text { WDL }\end{array}$ & USGS $^{1}$ & $\begin{array}{c}\text { Aerial } \\
\text { Photography }\end{array}$ & $\begin{array}{c}\text { NY Sea } \\
\text { Grant, UMD } \\
\end{array}$ \\
\hline 3/23/1969, 3/28/1969 & 1 & 5.1 & WDL & USGS & $\begin{array}{c}\text { Aerial } \\
\text { Photography }\end{array}$ & URI/NPS \\
\hline 7/01/1983, 7/01/1988 & 2 & 3.2 & WDL & USGS $^{1}$ & $\begin{array}{c}\text { Aerial } \\
\text { Photography }\end{array}$ & $\begin{array}{c}\text { NY Sea } \\
\text { Grant }\end{array}$ \\
\hline $\begin{array}{c}8 / 11 / 1993,9 / 11 / 1994 \\
8 / 21 / 1995,8 / 23 / 1996 \\
\text { 9/22/1997, 9/11/2001, } \\
10 / 16 / 2006\end{array}$ & 7 & 3.2 & HWL & $\begin{array}{c}\text { USGS/NPS } \\
2\end{array}$ & Field Survey & NPS/USGS \\
\hline $\begin{array}{c}12 / 03 / 1998 \\
10 / 21 / 1999,9 / 30 / 2000 \\
10 / 08 / 2002,4 / 25 / 2005 \\
4 / 30 / 2007,7 / 09 / 2009 \\
8 / 16 \& 8 / 29 / 2010 \\
8 / 31 / 2011,5 / 07 / 2012 \\
11 / 05 / 2012\end{array}$ & 11 & 2.0 & $\mathrm{MHW}^{* *}$ & USGS & Lidar & $\begin{array}{l}\text { USGS/NPS/ } \\
\text { NOAA/NASA }\end{array}$ \\
\hline $\begin{array}{c}3 / 13 / 2013,9 / 19 / 2013 \\
1 / 30 / 2014\end{array}$ & 3 & $1.2-5.5$ & $\mathrm{MHW}^{* *}$ & USGS & Field Survey & USGS \\
\hline
\end{tabular}

HWL - high water line; WDL - wet dry line; MHW - mean high water

*07/01/YEAR is a default date used when the actual survey date is unknown, or spanned over multiple dates. It is assumed that 1938 and 1962 are post- hurricane aerial surveys.

** The operational MHW for Fire Island, NY is $0.46 \mathrm{~m}$ NAVD88

1)http://pubs.usgs.gov/of/2010/1119/

2) https://irma.nps.gov/App/Reference/Profile/2174499 
837 Table 2. Mean and standard deviation over a 5 year period for wave height, wave period, wave 838 direction or propagation, and surge.

\begin{tabular}{llcccccccc}
\hline \multicolumn{2}{c}{ Years } & \multicolumn{2}{c}{ Wave Height $(\mathrm{m})$} & \multicolumn{2}{c}{ Wave Period (s) } & \multicolumn{2}{c}{ Wave Direction (deg) } & \multicolumn{2}{c}{ Surge $(\mathrm{m})$} \\
& $\mu$ & $\sigma$ & $\mu$ & $\sigma$ & $\mu$ & $\sigma$ & $\mu$ & $\sigma$ \\
\hline 1935 & 1939 & & & & & & & -0.21 & 0.17 \\
1940 & 1944 & & & & & & & -0.21 & 0.18 \\
1945 & 1949 & & & & & & -0.17 & 0.17 \\
1950 & 1954 & & & & & & -0.14 & 0.18 \\
1955 & 1959 & & & & & & & -0.11 & 0.18 \\
1960 & 1964 & & & & & & & -0.11 & 0.18 \\
1965 & 1969 & & & & & & & -0.09 & 0.18 \\
1970 & 1974 & & & & & & & -0.04 & 0.18 \\
1975 & 1979 & & & & & & & & \\
1980 & 1984 & 1.09 & 0.61 & 7.30 & 2.68 & -32.41 & 49.98 & -0.03 & 0.17 \\
1985 & 1989 & 1.07 & 0.58 & 6.89 & 2.58 & -27.86 & 49.14 & -0.03 & 0.16 \\
1990 & 1994 & 1.10 & 0.61 & 7.07 & 2.62 & -29.29 & 50.47 & -0.02 & 0.18 \\
1995 & 1999 & 1.12 & 0.63 & 7.02 & 2.63 & -25.35 & 49.72 & 0.04 & 0.17 \\
2000 & 2004 & 1.10 & 0.57 & 6.75 & 2.47 & -22.87 & 50.21 & 0.03 & 0.16 \\
2005 & 2009 & 1.07 & 0.59 & 7.02 & 2.53 & -25.70 & 52.28 & 0.08 & 0.18 \\
2010 & 2014 & 1.03 & 0.58 & 7.26 & 2.63 & -26.16 & 53.25 & 0.12 & 0.17 \\
& & & & & & & & & \\
Complete & 1.08 & 0.6 & 7.06 & 2.61 & -27.15 & 50.61 & -0.06 & 0.20 \\
\hline
\end{tabular}

839

840

841

842

843

844

845

846

847

848

849

850

851

852

853

854

855

856

857 


\section{Figure Captions}

Figure 1. Location map of Fire Island showing inner shelf geology (modified from Schwab et al, 2013), bathymetry, and the west (WGZ), central (CGZ) and east (EGZ) geologic zones.

Figure 2. Time series of mean-removed shoreline position. The gray boxes are data gaps over which residuals are averaged over long time periods and have high levels of uncertainty. Recent significant storms are represented by the arrows and letters: $\mathrm{O}=$ Oct 2005 nor'easter; $\mathrm{P}=$ 2007 Patriot's Day nor'easter; N = 2009 Nor'Ida storm; I = 2011 Hurricane Irene; S = 2012 Hurricance Sandy. The 3 geologic zones are also demarcated.

Figure 3. Long-term linear regression plot of shoreline change rates, with the $95 \%$ confidence band (dashed line) around the average rate (solid line). The vertical dashed lines show the divisions of the western, central and eastern geologic zones.

Figure 4: Lower order eigenfunctions which represent alongshore variability and amplitudes of the temporal coefficients for the mean-removed shoreline positions $(1933-2014)$. The eigenfunctions are shown in the left column (A, C and E) and the amplitudes in the right-hand column (B, D and F). The spatial distribution of the eignefuctions can be visually correlated to the 3 geologic zones shown in this figure and in Figure 1. The portion of the data set that includes Hurricane Sandy response and recovery is shown in red in the plots of the amplitude associated with each EOF mode. Note that the y-axes scale of EOF3 is different from EOF1 and $\mathrm{EOF} 2$ for visualization purposes.

Figure 5. Time series of a) significant wave height $\left(\mathrm{H}_{\mathrm{s}}, \mathrm{m}\right)$; b) mean wave period $\left(\mathrm{T}_{\mathrm{m}}, \mathrm{s}\right)$; c) mean direction of wave propagation ( $\alpha_{w}$, degrees from north); d) surge $\left(z_{s}, m\right)$; and e) temporal EOF coefficient (A). The filtered signal (red line) is a 90 day moving average in a-c and a 1 year moving average in $\mathrm{d}$.

Figure 6: Lower order eigenfunctions which represent alongshore variability and amplitudes of the temporal coefficients. The eigenfunctions are shown in the left column (A, C and E) and the amplitudes in the right column (B, D and F). The spatial distribution of the eignefuctions can be visually correlated to the 3 geologic zones shown in this figure and in Figure 1. The amplitude data are subsetted from Figure 5 in order to resolve the more recent time period from 1980 to 2014. The temporal coefficients are the same as those shown in Figure 5. The portion of the data set that includes Hurricane Sandy response and recovery is shown in red in the plots of the amplitude associated with each EOF mode. Storms of note over the past decade are indicated by the arrows and letters: $\mathrm{O}=$ Oct 2005 nor' easter; $\mathrm{P}=2007$ Patriot's Day nor' easter; $\mathrm{N}=2009$ Nor'Ida storm; I = 2011 Hurricane Irene; $S=2012$ Hurricance Sandy. Note that the y-axes scale of EOF3 is different from EOF1 and EOF2 for visualization.

Figure 7: Geomorphic responses associated with EOF modes: a) short-term change represented by net shoreline movement measured for Hurricane Sandy (Oct. 27 - Nov. 5, 2012) and a period 
904 of post-storm recovery (Mar. 13 - Sept. 19, 2013) showing the geomorphic response with 905 shoreline undulations of retreat and advance on the order of $1 \mathrm{~km}$ length-scale associated with 906 the variance in EOF1; b) long-term rates of shoreline change (see also, Figure 3) indicating 907 differential geomorphic behavoir of the island which is similar in character to the spatial variance 908 in EOF2; c) shoreline change rates for the period from 1988 to 1998, in which the intermediate 909 time-scale of shoreline variance demonstrated in EOF3 is shown in the shoreline behavior. 
Figures

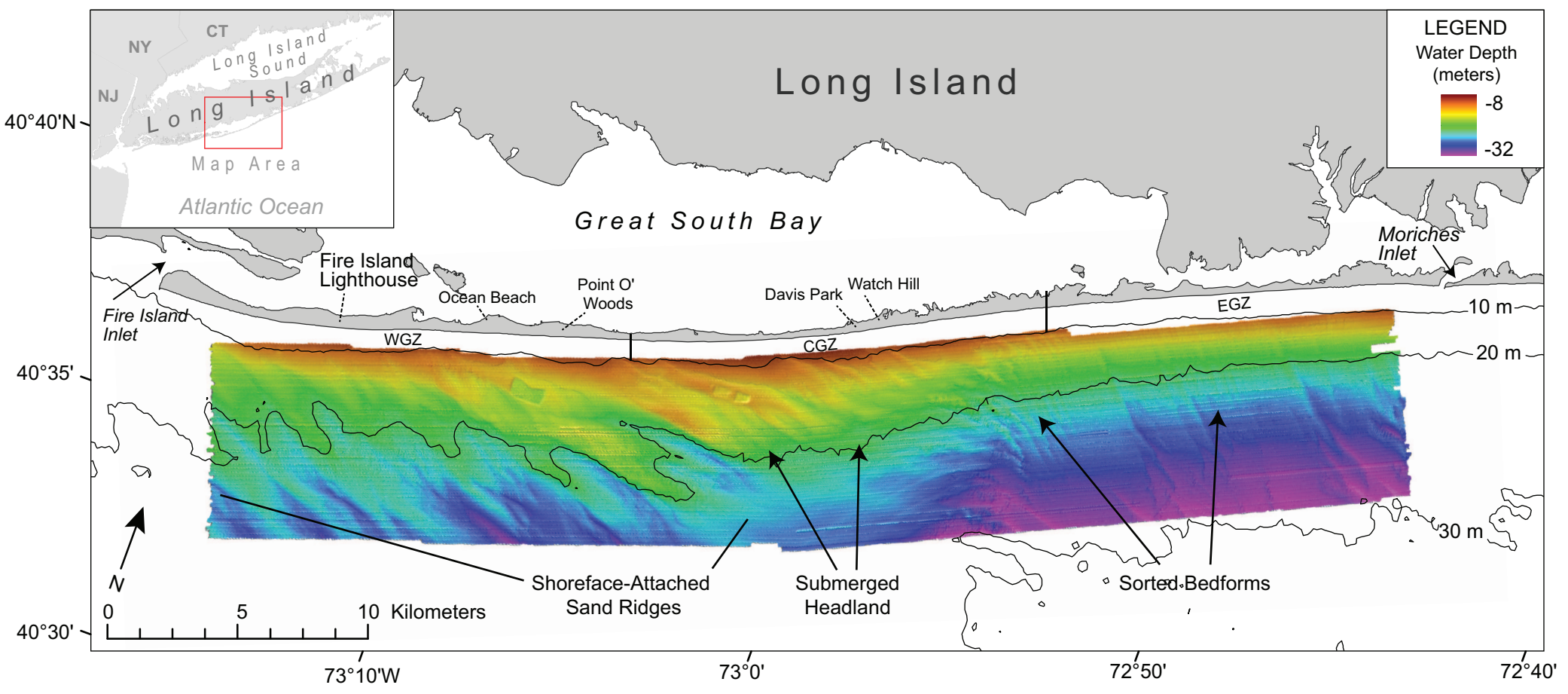

Figure 1 


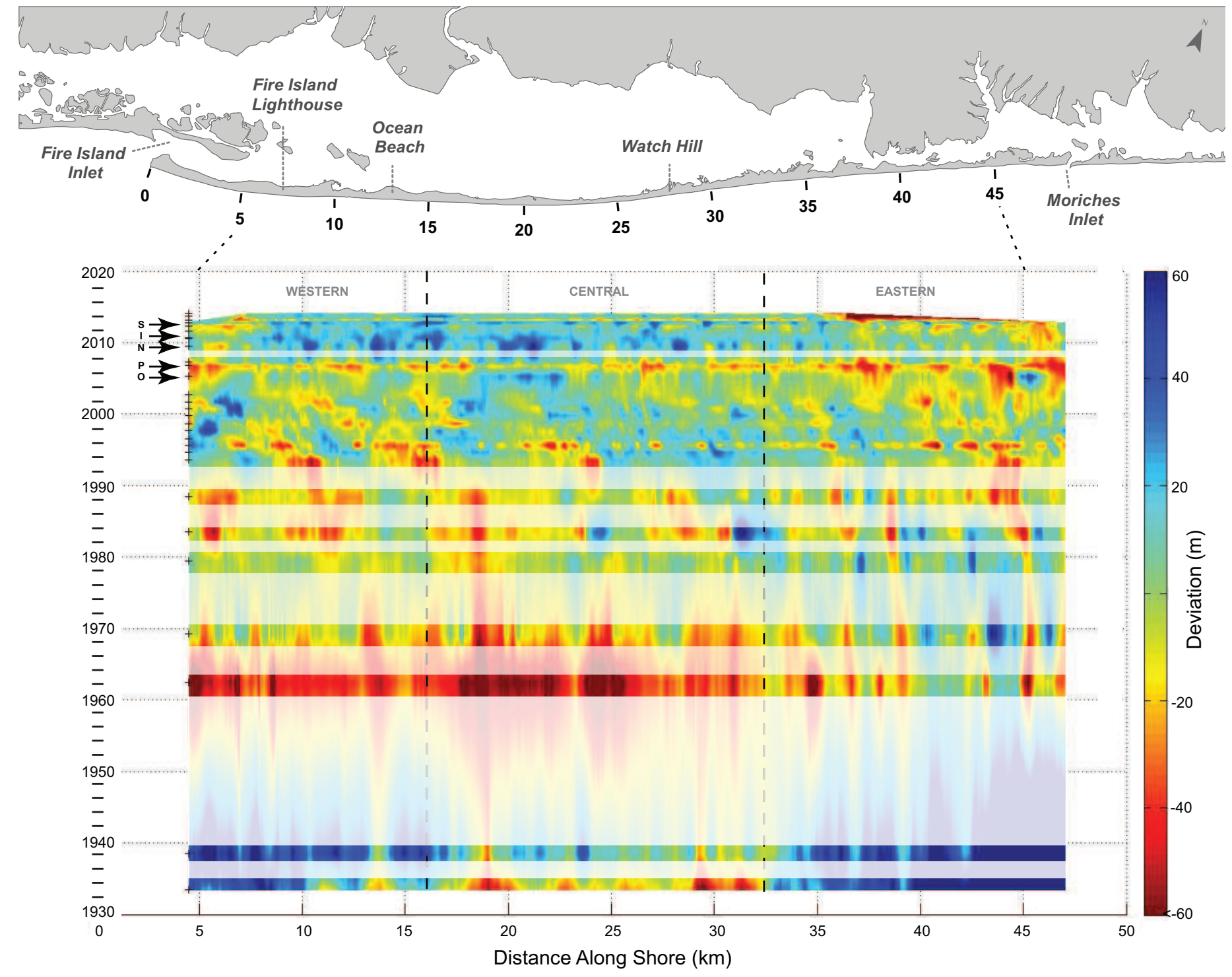

Figure 2 

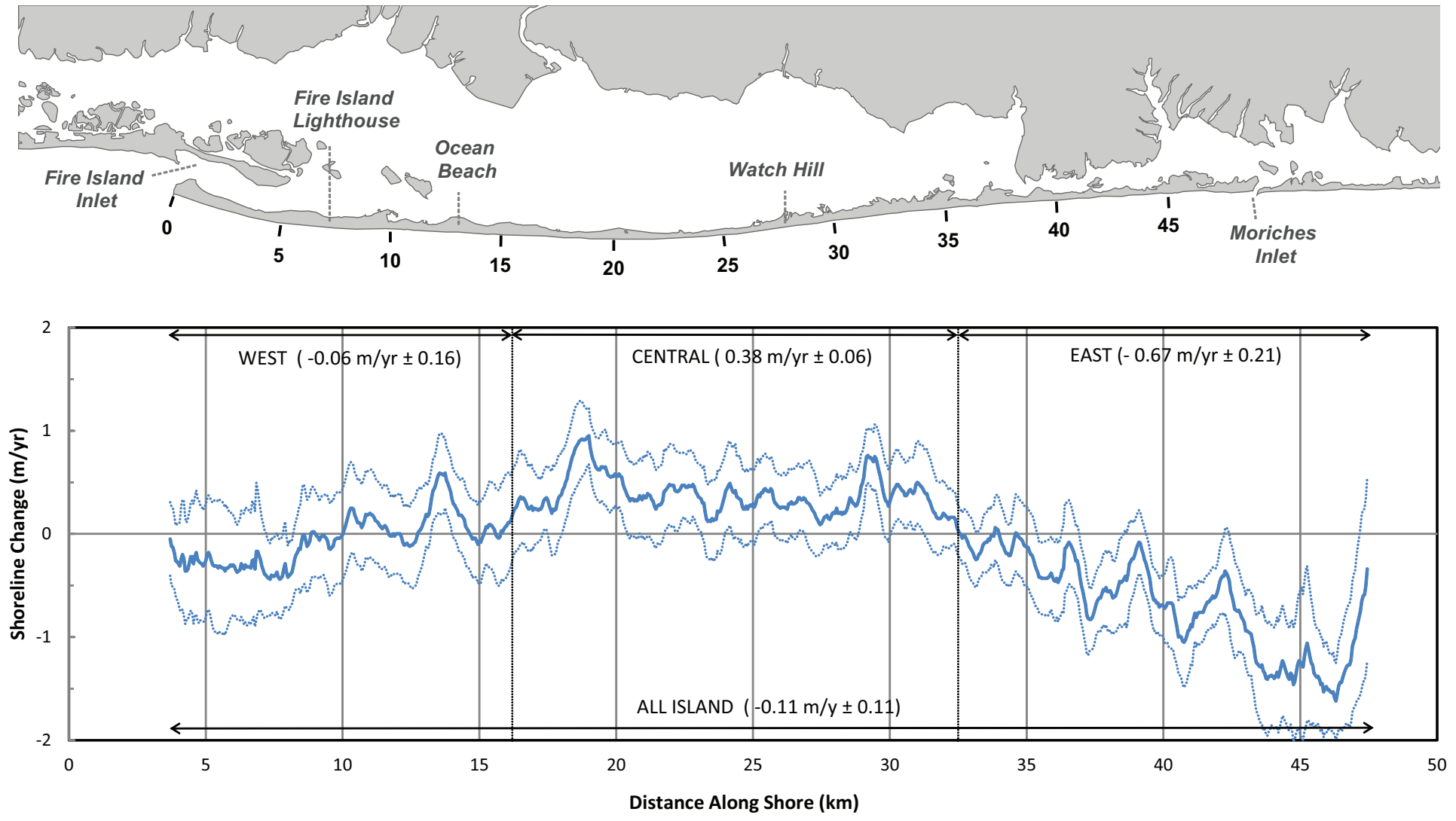

Figure 3. Long-term linear regression plot of shoreline change rates, with the $95 \%$ confidence band (dashed line) around the average rate (solid line). The vertical dashed lines show the divisions of the western, central and eastern geologic zones. 

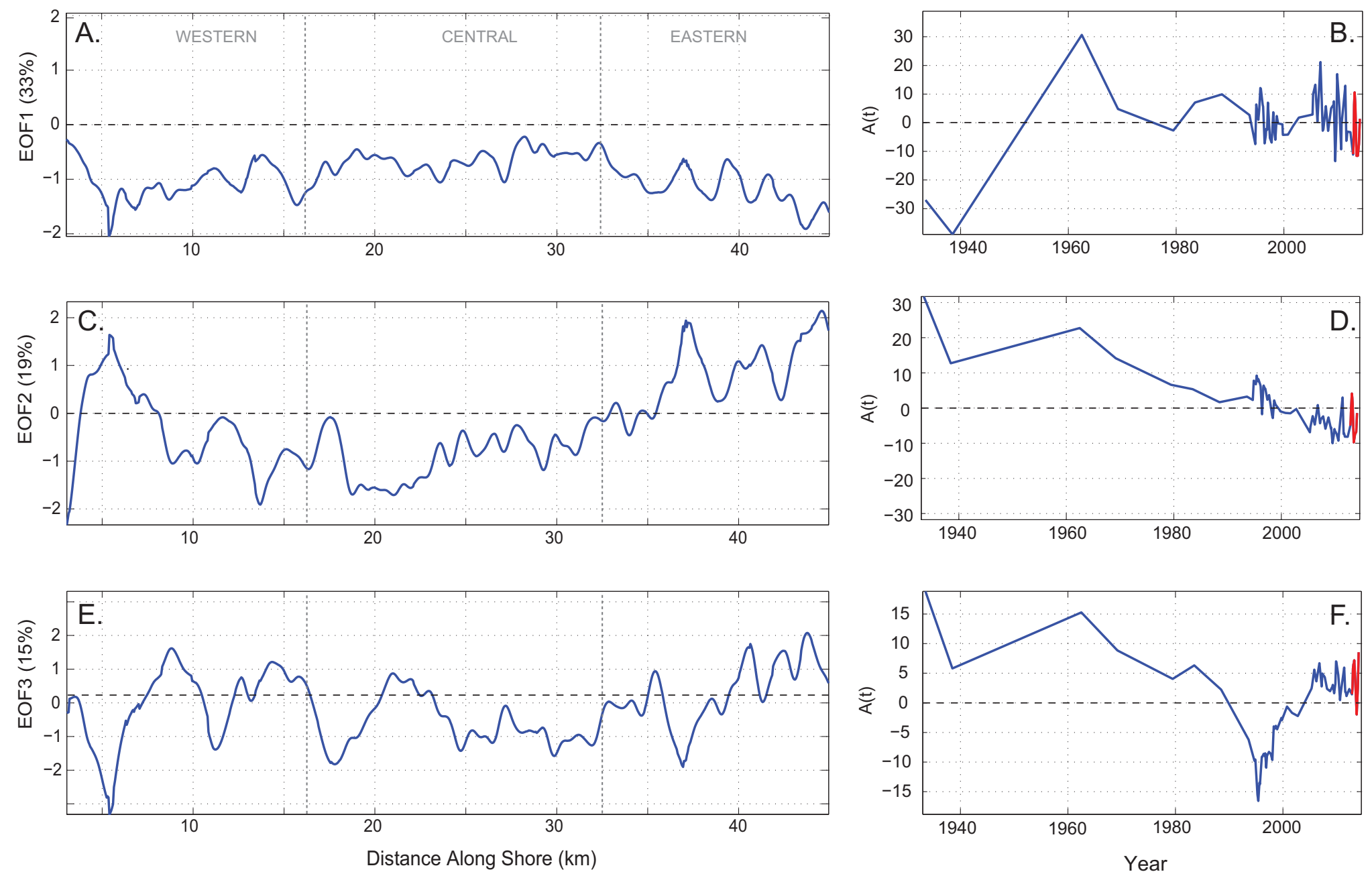

Figure 4 
Figure 5
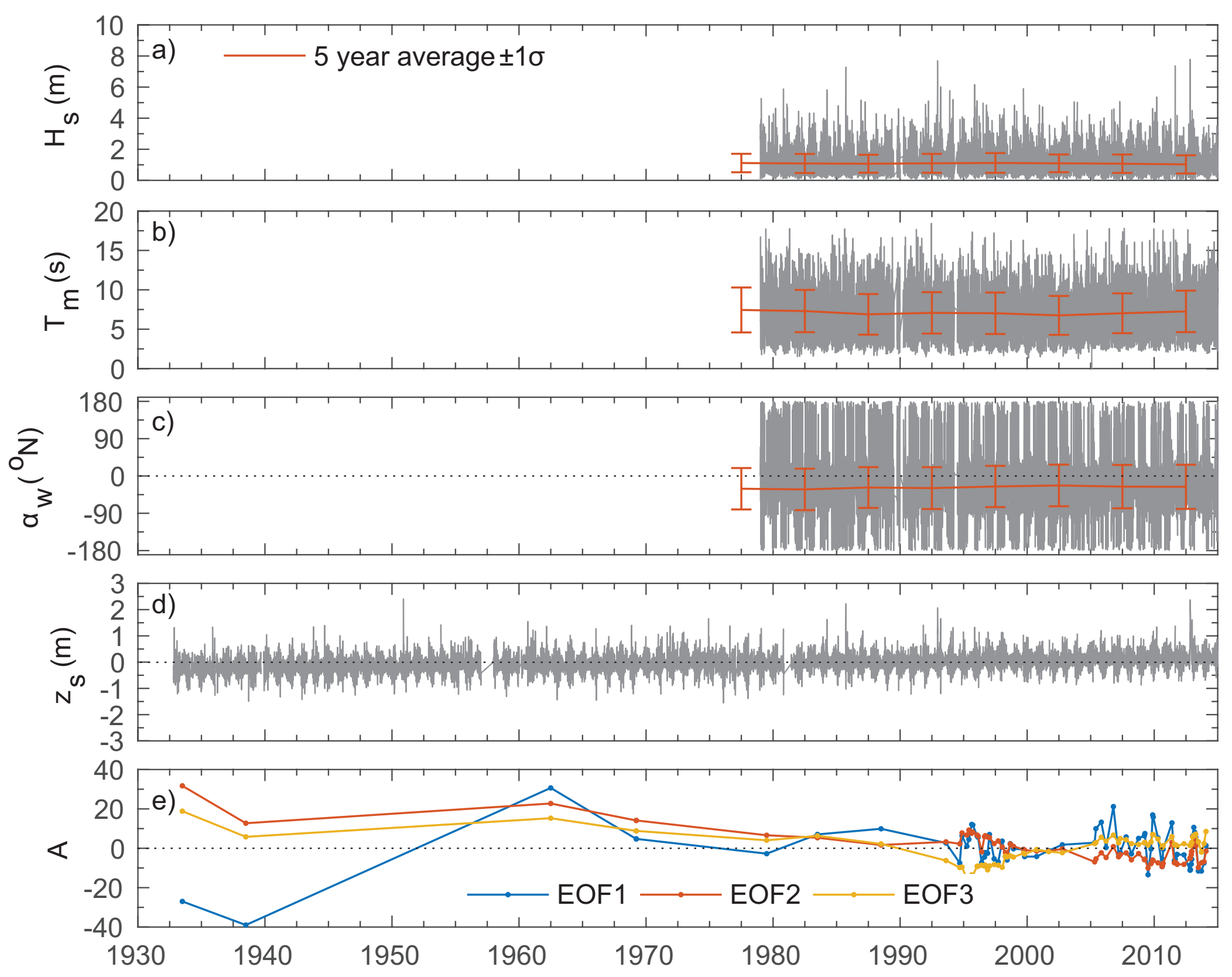

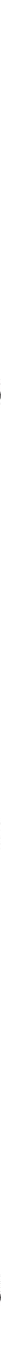

Figure 6 
Figure 7
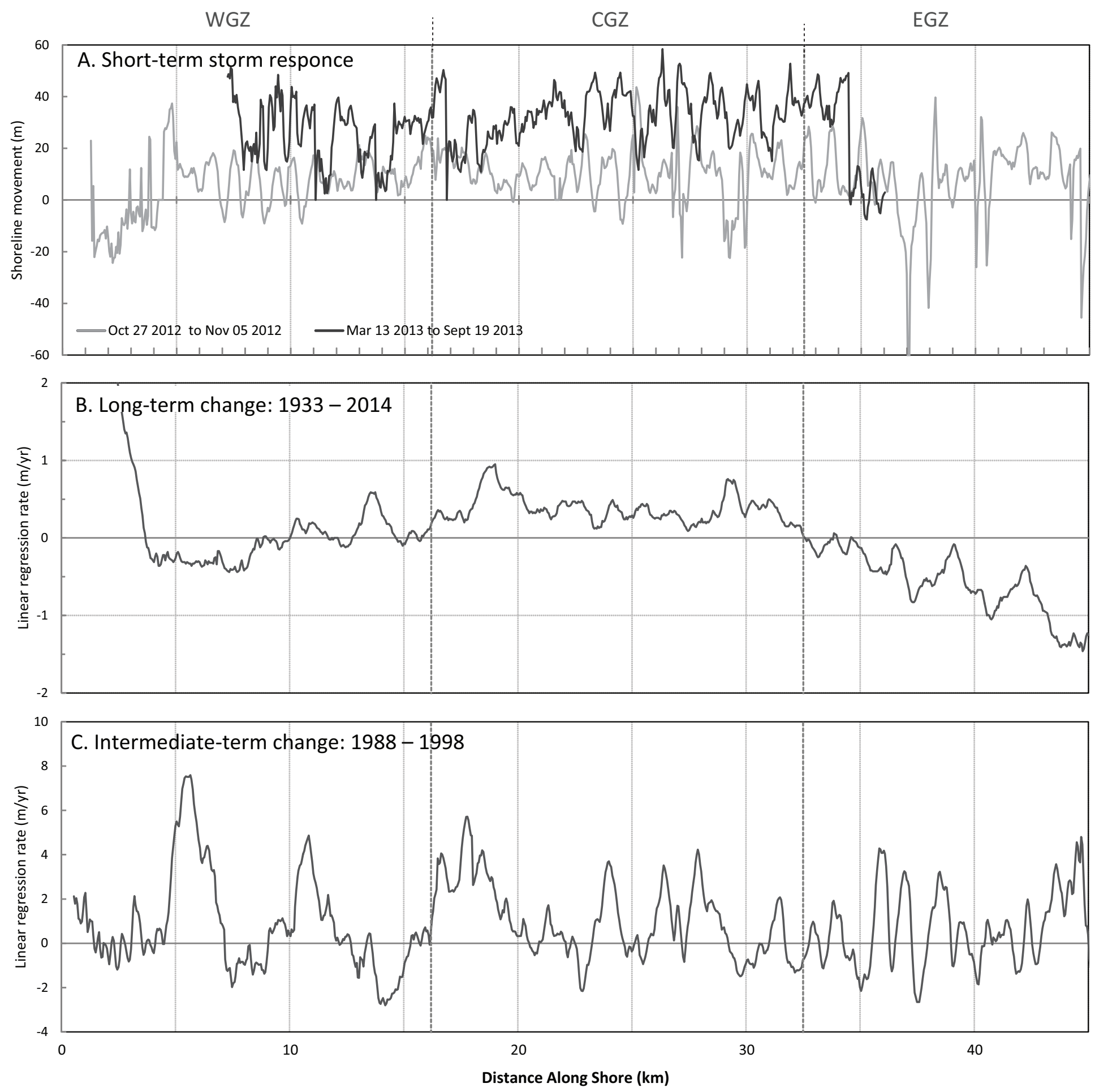